\title{
Effect of Soil Moisture and Soil Temperature on the Development of Stemphylium Blight of Lentil
}

\author{
M. I. Huq ${ }^{a^{*}}$ and A. Z. M. N. A. Khan \\ ${ }^{a}$ Regional Agricultural Research Station, Rahmatpur, Barisal and ${ }^{b}$ Department of Botany, Dhaka University, \\ Dhaka-1000, Bangladesh
}

\begin{abstract}
The soil moisture and the soil temperature at $7 \mathrm{a} . \mathrm{m}$. and $1 \mathrm{p} . \mathrm{m}$. were monitored in the lentil field. During the years of studies it was observed that the highest PDI was recorded on March 12 with corresponding soil temperature at 7 a.m. and 1 p.m. and soil moisture were maximum while the lowest PDI was recorded on January 30 when the aforesaid soil factors were minimum. The soil temperature and soil moisture were found positively correlated with disease development.
\end{abstract}

Key words: Stemphylium blight, soil moisture, soil temperature and lentil

\section{Introduction}

Lentil (Lens culinaris Medik.) is the second most important pulse crop in terms of both area and production and rates the highest consumers' preference. It contributes $25 \%$ of the total pulse production (Anonymous, 1991). The crop is found to grow everywhere in the country. The production of the crop is decreasing every year due to cultural and genetic factors such as low genetic potentials of the existing varieties, poor response to high input, and susceptibility to disease, low acreage and delay in sowing by the farmers (Anonymous,1989). Among the factors mentioned above susceptibility to disease is very important.

As many as 15 pathogens causing 17 diseases of lentil crop have so far been recorded in Bangladesh (Ahmed, 1985). The major diseases affecting the crop are Stemphylium blight (Stemphylium sp), Rust (Uromyces fabae L.) and Foot rot (Sclerotium rolfsii Sacc.).Of the major diseases, Stemphylium blight of lentil was recorded in Bangladesh by Bakr and Zahid (1986), In India by Sen Gupta and Das (1964) and Nene et al. (1984). In Iran by Kaiser (1972) and by Simay (1990) in Hungary. The disease is a serious constraint in lentil cultivation and is widespread throughout the country with the highest severity in Jessor, Pabna, Kustia, Faridpur, Madaripur, and Dhaka (Bakr and Ahmed, 1992). In the recent years, the disease is also a threat to lentil cultivation in the southern parts of the country like Barisal and Bhola districts.
Stemphylium blight of lentil caused by Stemphylium botryosum is one of the major diseases of much economic importance. In Indian sub-continent the disease has been continued to be a serious threat to the successful cultivation of lentil. The disease can infect the crop severely. The necrotrophic fungus, Stemphylium botryosum has been reported to over summer on dead plant parts during non-crop season. Afterwards it multiplies with the influence of some favourable micro-climatic factors and spreads by wind. The incidence and development of the disease during the crop season is influenced by various meteorological and soil factors.

The symptom of the disease is manifested by the appearance of small pinhead gray spots on the leaflets and covering rapidly the entire leaf surface, which then spread to the twigs within a few days. In severe condition almost all the leaflets are blighted and the plants become defoliated leaving immature green pods and some terminal leaves. In 1993, Zahid and Hossain reported that almost similar symptom developed in chickpea. The disease is increasing tremendously in the recent years and continued to be a serious threat to the successful cultivation of lentil. Because of the increase in severity, the disease has already gained much more importance and reported to incur $80-92.35 \%$ crop loss (Bakr and Ahmed, 1992.). In India, the intensity of the disease was $82.55 \%$ and the loss was recorded as $93.4 \%$ (Singh et al., 1990).

\footnotetext{
* Corresponding author: E-mail:
} 
However, to study the effect of soil moisture and temperature on the initiation and development of disease the present experiment has been designed.

\section{Materials and Methods}

The experiment was conducted at Regional Agricultural Research Station, Rahmatpur, and Barisal. The experiment was laid out in a well managed piece of land using RCB design having three replications. The unit plot size was $4 \mathrm{~m} \mathrm{x}$ $3 \mathrm{~m}$ with $25 \mathrm{~cm}$ row to row spacing. The seeds were sown in the rows in continuous manner. A susceptible genotype L - 81124 was sown on different dates, viz., November 01, 10, 20, 30, December 10, 20 and 30. After completion of the sowing, the experiment was kept under constant watch from sowing up to harvest. The data on soil factors such as soil temperature and soil moisture with corresponding sowing dates were recorded. The disease data were recorded from 25 randomly tagged plants/plot on the basis of 1-9 scoring scale and Percent Disease Index (PDI) was computed on the basis of the recorded data according to the formula (Wheeler, 1969). 1 = No leaf infected, 2 = Few scattered leaflets infected but no twigs blighted, $3=$ Few scattered leaflets infected and 5\% twigs blighted, $4=5-20 \%$ leaflets infected and up to $10 \%$ twigs blighted, $5=20-40 \%$ leaflets infected and up to $20 \%$ twigs blighted, $6=40-70 \%$ leaflets infected and up to $30 \%$ twigs blighted, $7=40-70 \%$ leaflets infected and up to $50 \%$ twigs blighted, $8=70-90 \%$ leaflets infected and up to $70 \%$ twigs blighted, $9=>90 \%$ leaflets infected and $>70 \%$ twigs blighted.

To study the effect of soil moisture and soil temperature on development of disease, soil moisture and soil temperature were monitored every day in the experimental field started from the date of 1 st sowing and continued up to the date of harvest (March 20) of last sowing.

\section{Soil temperature}

It was recorded with the help of a thermometer by placing to a depth of $1 \mathrm{~cm}$ from the soil surface. Reading was taken twice daily at 7a.m. and 1p.m.

\section{Soil moisture}

Soil samples were collected from 5 randomly selected spots of the experimental plot with the help of augur at every alternate day. The collected soil from different spots were mixed thoroughly and taken in aluminum pots and dried in the oven for $24 \mathrm{hr}$ at $65^{\circ} \mathrm{C}$. The percent soil moisture content was calculated on the basis of the formula described below (Anonymous, 1989)

Percent moisture content $=\frac{\text { Initial weight }- \text { Final weight }}{\text { Initial weight }} \times 100$

The percent data thus obtained were subjected to arcsine transformation and analyzed statistically and means were compared by DMRT (Steele and Torrie, 1980)

\section{Results and Discussion}

Influence of soil temperature and soil moisture on disease development during 1998-1999 was shown in the Fig.1 Data on Percent Disease Index, soil temperature $\left({ }^{\circ} \mathrm{C}\right)$ at $7 \mathrm{a} . \mathrm{m}$. and 1p.m. and soil moisture were noted.
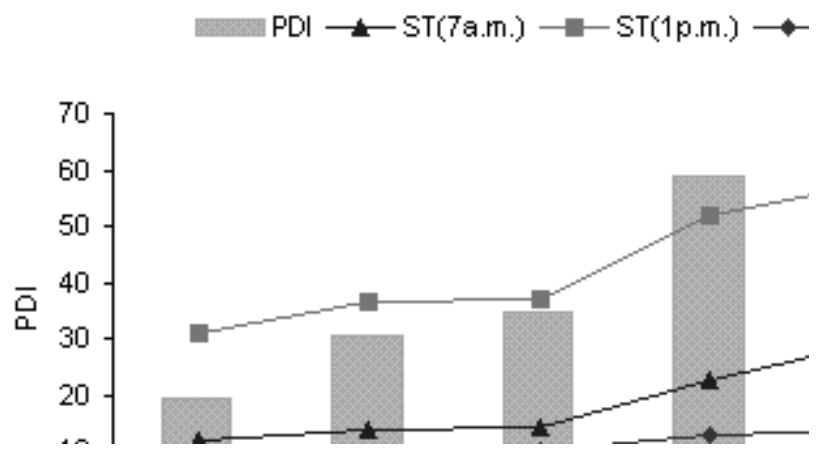

Fig. 1: Disease development in relation to soil factors during 1998-1999

It is found in Fig. 1. that in 1998-1999 both soil moisture and soil temperature had significant effect $(1 \%$ level) on disease severity and correlated positively with disease development. The PDI increased gradually with increase in soil temperature from $12^{\circ} \mathrm{C}-29.6^{\circ} \mathrm{C}$ at 7 a.m., $30.9^{\circ} \mathrm{C}-58^{\circ} \mathrm{C}$ at $1 \mathrm{p} . \mathrm{m}$. and soil moisture $1.7-14 \%$. In respect of observation dates the highest PDI was recorded on March 12, when corresponding soil temperature at 7a.m. and 1p.m. and soil moisture were maximum. On the other hand, the lowest PDI was recorded on January 30 when the aforesaid soil factors were minimum. The progressive increase in disease severity was favoured by progressive increase in soil temperature and soil moisture. 
Relationship among soil temperature, soil moisture and PDI during 1998-1999

The relation between PDI and soil temperature at 7a.m. and 1p.m. exhibited positive linear correlation showing equations $y=2.54 x-5.1013$ and $y=1.6916 x-30.56$, the value of coefficient of regressions were $\mathrm{R}^{2}=0.9337$ and $\mathrm{R}^{2}=0.9872$, respectively. (Figs.2-3). Soil moisture exhibited positive linear correlation with PDI showing the equation, $\mathrm{y}=3.1066 \mathrm{x}-$ 16.217 and coefficient of regression $\mathrm{R}^{2}=0.8384$ (Fig.4).

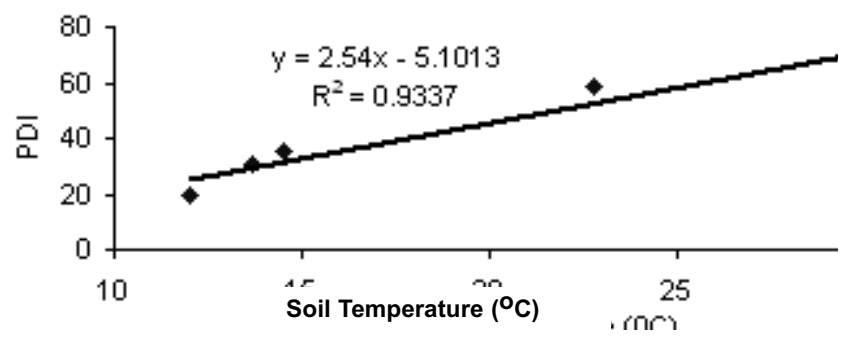

Fig. 2: Relationship between soil temperature (7 a.m) and PDI in 1998-1999

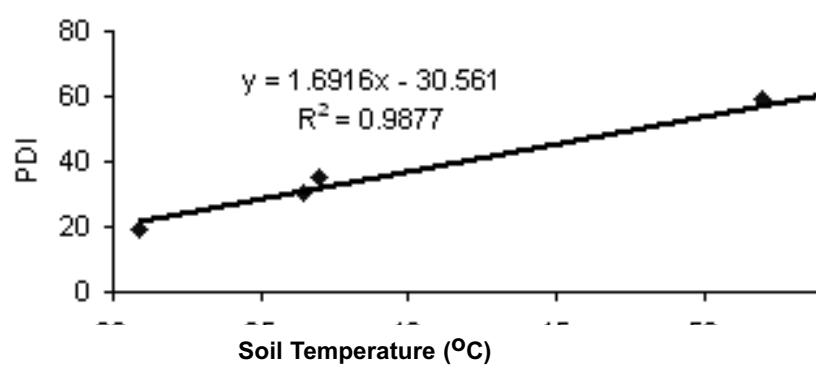

Fig. 3: Relationship between soil temperature (1p.m) and PDI in 1998-1999
Effect of soil temperature and soil moisture on disease development during 1999-2000 was shown in Fig. 5. Data were noted on PDI, soil temperature $\left({ }^{\circ} \mathrm{C}\right)$ at $7 \mathrm{a} . \mathrm{m}$. and $1 \mathrm{p} . \mathrm{m}$. and soil moisture.

It is evident in the figure that the disease severity was increasing significantly from $15.8-73.6 \%$ along with the increase in soil temperature from $17.5-30^{\circ} \mathrm{C}$ and $32.8-49.8^{\circ} \mathrm{C}$ at 7 a.m. and 1 p.m. and soil moisture $2.5-18.8 \%$, respectively. The disease development from the date of initiation (January 30) was favoured by soil factors and continued up to March 12 when the highest PDI (73.6) was recorded. The progress of disease was related to progressive increase in soil temperature and moisture. The soil temperature, which at $1 \mathrm{p} . \mathrm{m}$. is more congenial for disease development in presence of soil moisture content.

\section{Relationship among soil temperature, soil moisture and PDI during 1999-2000}

Soil temperature at 7a.m. and 1p.m. exhibited a linear positive correlation with disease severity showing the equations $y=2.8215 x-17.877$ and $y=2.8258 x-64.708$ and regression coefficient $\mathrm{R}^{2}=0.7772$ and $\mathrm{R}^{2}=0.8635$ respectively. This indicated that with the increase in soil temperature at $7 \mathrm{a} . \mathrm{m}$. and 1p.m. the PDI was found to increase (Fig. 6-7). The soil moisture also exhibited a positive linear correlation which was linear showing the equation, $y=3.0722+14.726$ and coefficient of regression, $\mathrm{R}^{2}=0.9716$ (Fig. 8).

With relation to Influence of soil temperature and soil moisture on disease development during 2000-2001 was shown in

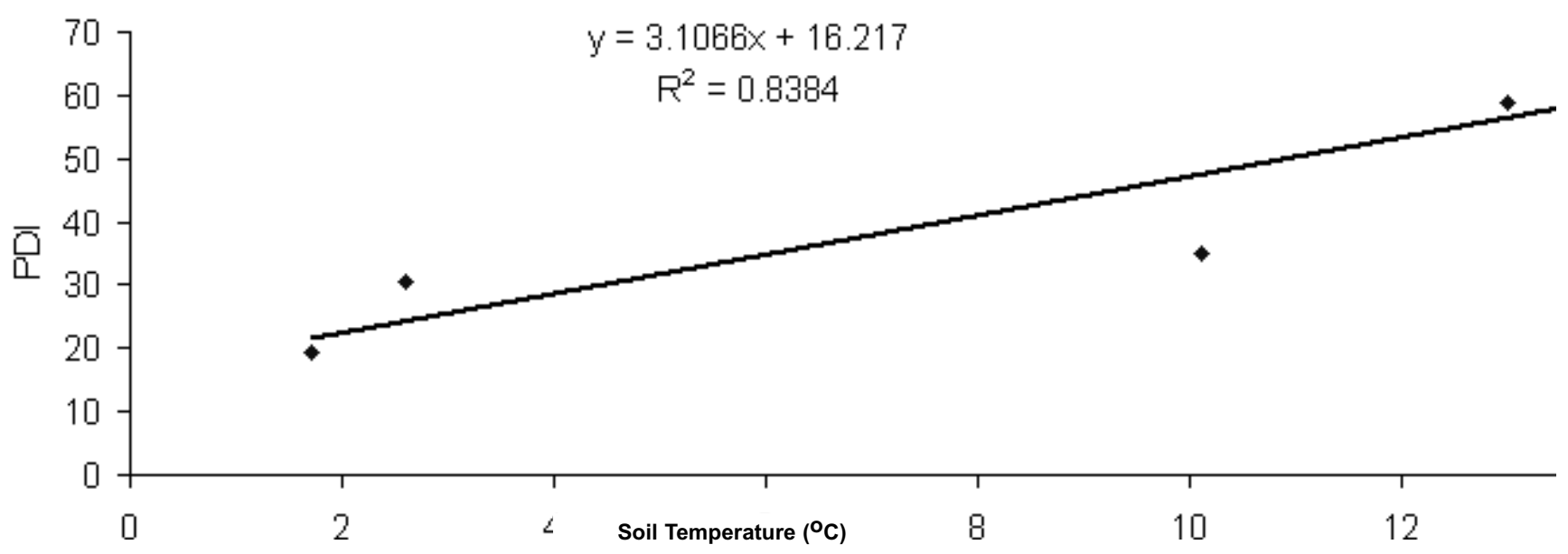

Fig. 4: Relationship between soil moiusture and PDI in 1998-999 


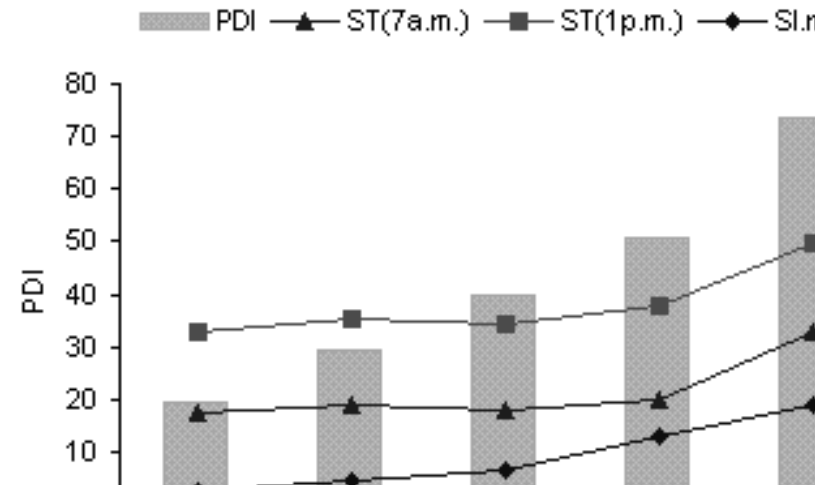

Fig. 5: Disease development in relation to soil factors during 1999-2000

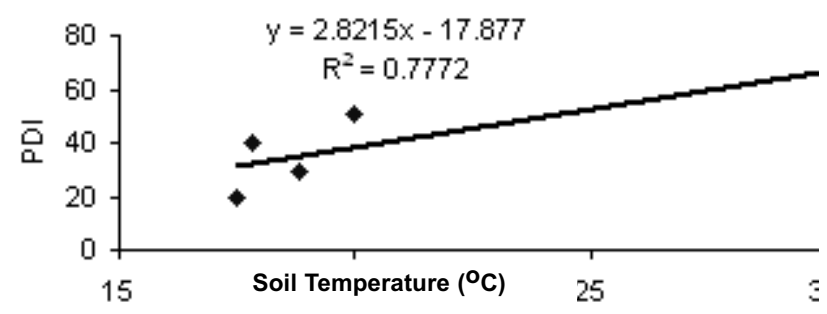

Fig. 6: Relationship between soil temp. (7a.m) and PDI in 1999-2000

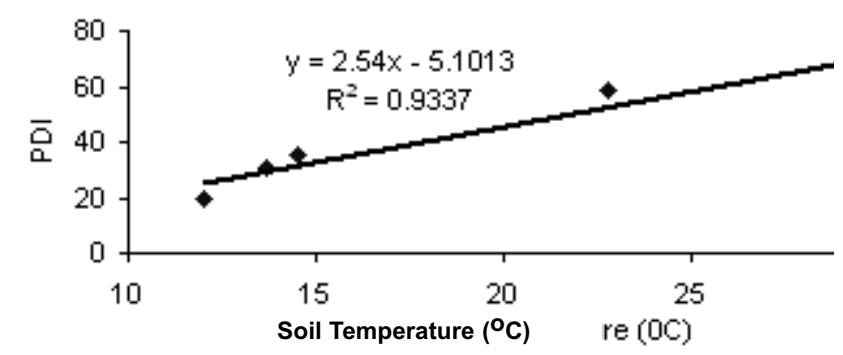

Fig. 7: Relationship between soil temperature (1 p.m) and PDI in 1999-2000

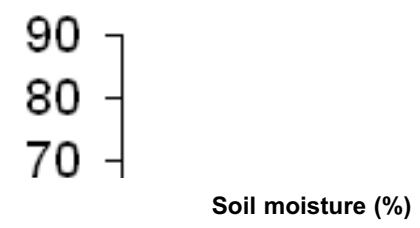

Fig. 8: Relationship between soil moisture and PDI in 2000-2001

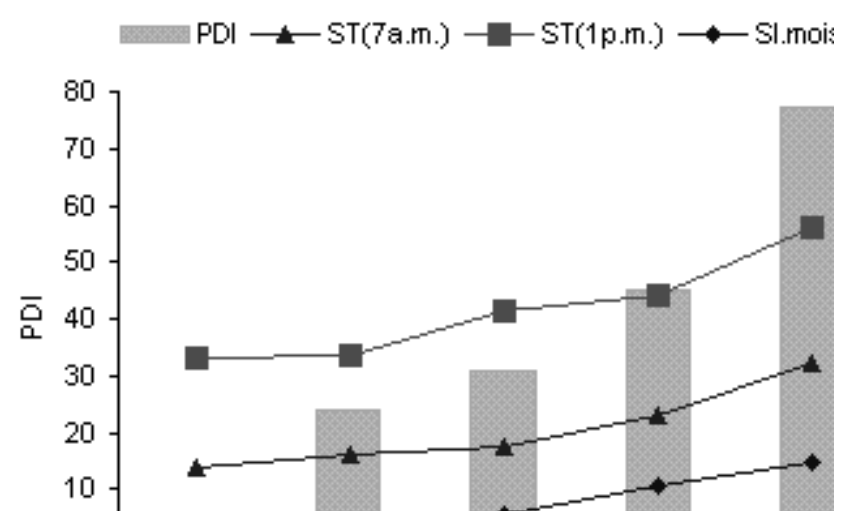

Fig. 9: Disease development in relation to soil factors during 2000-2001

Fig 9. Data on Percent Disease Index, soil temperature $\left({ }^{\circ} \mathrm{C}\right)$ at 7 a.m. and 1p.m. and soil moisture were recorded.

It is revealed from the figure that during 2000-2001 the disease first appeared on February 10 when the soil temperature at 7a.m. and 1p.m. were $16.3^{\circ} \mathrm{C}$ and $33.5^{\circ} \mathrm{C}$ and soil moisture $3.2 \%$. Then the disease was increasing progressively and reached to the maximum on March 12 when soil temperature at $7 \mathrm{a} . \mathrm{m}$ and $1 \mathrm{p} . \mathrm{m}$. were $32^{\circ} \mathrm{Cand} 56^{\circ} \mathrm{C}$, respectively and soil moisture was $14.5 \%$. The progress of the disease was influenced by the increase in soil temperature and soil moisture.

\section{Relationship among soil temperature, soil moisture and PDI during 2000-2001}

Soil temperature at 7a.m. and 1p.m. showed linear positive correlation with PDI, where the equations $\mathrm{y}=3.3249 \mathrm{x}$ 29.704 and $y=2.469 x-63.464$ and coefficients of regression $\mathrm{R}_{2}=0.9962$ and $\mathrm{R}_{2}=0.9408$, respectively (Fig. $10-11$ ), gave the best fit.

The correlation indicated that PDI was found to increase with the increase in soil temperature and soil moisture. The soil moisture also responded positively with PDI showing the equation $y=2.469 x+63.868$ and coefficient of regression, $\mathrm{R}_{2}=0.9716$ (Fig. 12).

During the crop period soil factors such as soil moisture and soil temperature had influence on disease development. Of the temperatures (soil temperature at 7a.m. and soil temperature at $1 \mathrm{p} . \mathrm{m}$.), which at $1 \mathrm{p} . \mathrm{m}$. was more effective for appearance and development of disease. Increased soil moisture 


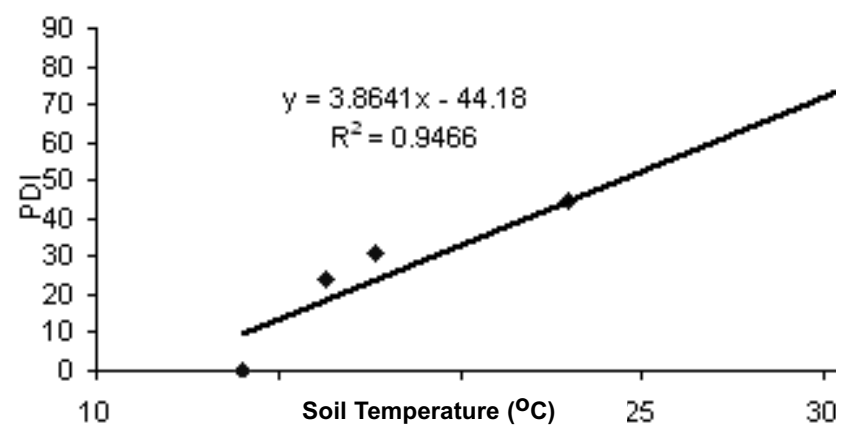

Fig. 10: Relationship between soil temperature (7p.m) and PDI in 2000-2001

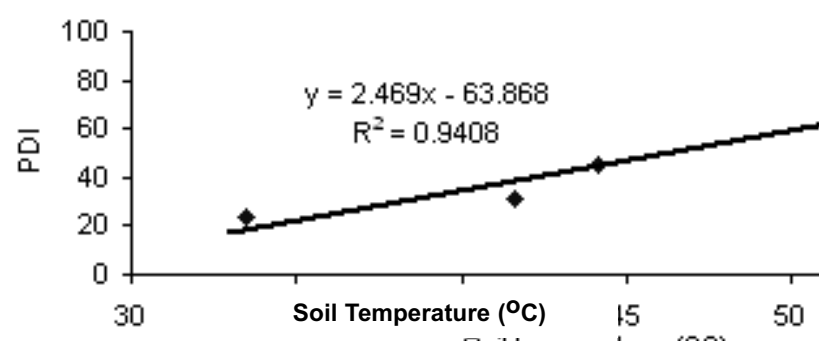

Fig. 11: Relationship between soil temp. (1 p.m) and PDI in 2000-2001

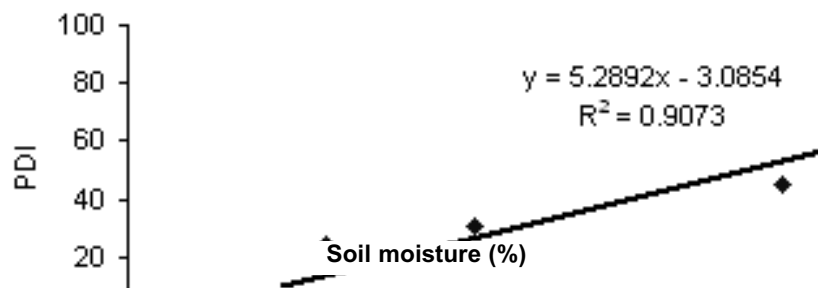

Fig. 12: Relationship between soil moisture and PDI in 2000-2001

content and temperature might be the promoting factor for primary infection from plant debrises (Bhandari et al., 1993). The present findings of the three years studies were in supported of the opinion.

\section{Conclusion}

From the findings of three consecutive years it could be indicated that the highest severity of Stemphylium blight of lentil was recorded when the soil factors were maximum during the month of March. The disease development was found positively correlated with the increase in soil temperature and soil moisture. However, it could be recommended that lentil should be grown in the early winter to escape the Stemphylium blight as soil temperature and moisture are found minimum in that period.

\section{References}

Ahmed H. U. (1985). Disease problems of pulses and oilseed crops in Bangladesh Paper presented in the first National Plant Pathology Conference of Bangladesh Phytopathological Society held at BARI, Joydebpur Gazipur during April. pp. 13-14

Anonymous. (1989). Advances in Pulses Research in Bangladesh. Proceedings of Second National Workshop on Pulse. 6-8 June. Joydebpur Gazipur. pp. 254.

Anonymous. (1991). Statistical Year Book of Bangladesh. Bangladesh Bureau of Stat. pp. 186.

Bakr M. A. and Zahid I. (1986). Stemphylium blights a new foliar disease of lentil in Bangladesh. Bangladesh J. of Plant Pathol. 2(1): 69-70.

Bakr M. A. and Ahmed F. (1992). Development of Stemphylium blight of lentil and it's control. Bangladesh J. Plant Pathol. 8(1\&2): 39-40.

Bhandari T. P. S., Singh R. N. and Roy A. J. (1993). Role of meteorological factors on disease index of black spot of rose. Indian J. Mycol. Pl. Pathol. 23 (1): 3841.

Kaiser, W. J. (1972). Occurrence of three fungal diseases of chickpea in Irsn. FAO Plant Protec. Bull. 20: 74 -78.

Nene, Y. L., Sheila V. K. and Sharma S. B. (19840. Stemphylium sarciniformae. Wilt. (In a world list of chickpea (Cicer arietinum L.) and pegionpea (Cajanus cajan. L. Millsp.) Pathogen. ICRISAT Patancheru P. O. Andhra Pradesh, pp.502.

Simay E. I. (1990). Occurrence of Epicoccum and Stemphylium leaf spot of Lens culinaris Lens- News Letters (ICARDA) Lentil Experimental News Service. 17(1): 28-30. 
Singh B. P., Singh S. P. and Mohammed A. (1990). Economic efficacy of different fungicides for the control of leaf spot of cauliflower. Indian Phytopath. 43(2): 207-209.

Steele R. G. D. and Torrie J. D. (1980). Principles and procedures of statistics. McGraw-Hill Book Co., New York. pp. 461.

Wheeler B. E. J. (1969). An Introduction to Plant Diseases. John Wiley and Sons. Ltd. London. pp. 301.
Sen Gupta P. K. and Das C. R. (1964). Effect of vitamins, hormones and trace elements on the growth and sporulation of Stemphylium sarciniformae, causal organism of leaf spot of gram. Plant Dis. Reptr. 48: 37-40.

Zahid, M. I. and Hossain M. (1993). Stemphylium blights a foliar disease of chickpea in Bangladesh. Bangladesh J. Pl. Pathol. 9(1\&2): 41.

Received : August 03, 2009;

Accepted : March 14, 2010 